\title{
Phosphate Solubilization by Endophytic Bacteria isolated from Oryza sativa
}

\author{
Madhusmita Borah ${ }^{1}$, Pompi Das ${ }^{2}$, Susanta Sarmah Pathak ${ }^{2}$, \\ Robin Chandra Boro ${ }^{2}$ and Madhumita Barooah ${ }^{2 *}$
}

${ }^{1}$ Centre for Biotechnology and Bioinformatics, Dibrugarh University, Dibrugarh, Assam, India

${ }^{2}$ Department of Agricultural Biotechnology, Assam Agricultural University,

Jorhat-13, Assam, India

*Corresponding author

\section{A B S T R A C T}

\begin{tabular}{|l|}
\hline Ke y w or d s \\
Endophytes, \\
Phosphate \\
solubilization, \\
Biofertilizer, \\
Tricalcium phosphate, \\
Aluminium phosphate, \\
Ferric phosphate, DAI \\
(Days after \\
Inoculation). \\
\hline Article Info \\
\hline Accepted: \\
23 September 2017 \\
Available Online: \\
10 October 2017 \\
\hline \hline
\end{tabular}

Endophytic bacteria isolated from the Oryza sativa plant were evaluated for phosphate solubilisation. Five of these isolates that showed good phosphate solubilising activity were characterised at molecular level and tested for phosphate solubilisation using three different sources viz tricalcium phosphate $(\mathrm{TCP})$, aluminium phosphate $\left(\mathrm{AlPO}_{4}\right)$ and iron phosphate $\left(\mathrm{FePO}_{4}\right)$. Based on 16s rRNA gene sequence analysis the isolates were identified as Pantoeaa ananatis, Pseudomonas putida, Brevibacillus agri, Bacillus subtilis and Bacillus megaterium. The isolates showed maximum phosphate solubilizing activity on the $6^{\text {th }}$ day of incubation (DAI) with a concomitant decrease in the $\mathrm{pH}$ of the medium. Bacillus subtilis (LP31 L03) showed highest phosphate solubilising activity $(57.58 \pm 0.65$, $6.10 \pm 0.65,7.65 \pm 0.30 \mu \mathrm{g} / \mathrm{ml}$ ) in TCP, $\mathrm{AlPO}_{4}$ and $\mathrm{FePO}_{4}$ respectively. The isolates under study were able to easily solubilize TCP followed by $\mathrm{FePO}_{4}$. Among the sources tested, $\mathrm{AlPO}_{4}$ was least solubilised. The decrease in $\mathrm{pH}$ of the medium inoculated with Bacillus subtilis (LP31 L03) was recorded as $4.02 \pm 0.12,3.33 \pm 0.19$ and $3.8 \pm 0.14$ in TCP, $\mathrm{AlPO}_{4}$ and $\mathrm{FePO}_{4}$ respectively on $6^{\text {th }}$ DAI. The study reports that endophytic isolates have good phosphate solubilizing activity and indicates and can be good candidate strains for developing an effective phosphate solubilizing biofertilizer.

\section{Introduction}

Phosphorus is the most essential key element in the nutrition of plants, next only to nitrogen $(\mathrm{N})$. It is one of the structural components of nucleic acids, phospholipids and adenosine triphosphate (ATP) and plays a vital role in most of the important metabolic processes in plant including photosynthesis, respiration, signal transduction, energy transfer and macromolecular biosynthesis (Khan et al., 2010). Phosphorous is abundantly present in soil, mostly in the form of insoluble mineral complexes which the plants cannot directly absorb (Rengel and Marschner, 2005). Only $0.1 \%$ of the total phosphorous exists in a soluble form available for plant uptake (Zou et al., 1992). Under natural conditions phosphorous rapidly precipitates as sparingly soluble complexes of different kinds of phosphates. In acid agricultural soils phosphorous occurs in complexes like variscite $\left(\mathrm{AlPO}_{4} \cdot 2 \mathrm{H}_{2} \mathrm{O}\right)$ and strengite $\left(\mathrm{FePO}_{4} \cdot 2 \mathrm{H}_{2} \mathrm{O}\right)$ that are very resistance to solubilisation (Richardson 2001). The availability of phosphorous depends on its solubility which is strongly influenced by the plant physiology and soil microorganisms. These factors influence the solubilisation of insoluble forms of phosphorous such as 
tricalcium phosphate $\left(\mathrm{Ca}_{3} \mathrm{PO}_{4}\right)_{2}$, aluminium phosphate $\left(\mathrm{Al}_{3} \mathrm{PO}_{4}\right)$, iron phosphate $\left(\mathrm{Fe}_{3} \mathrm{PO}_{4}\right)$ (Sharma et al., 2013). Phosphate solubilizing bacteria constitute about $1-50 \%$ of the total population of cultivable microorganisms in the soil (Khan et al., 2009). Among the phosphate solubilising microorganisms bacteria are the most effective (Afzal et al., 2008). Bacterial endophytes living within the tissues of higher plants are known to aid in plant growth and promotion by production of phytohormones and solubilising complex minerals like phosphorous present in soil (Vendan et al., 2010). This trait can be of interest when developing an efficient phosphate solubilising biofertilizer. The introduction of beneficial bacteria as efficient inoculants in the soil can be considered an important strategy for sustainable agricultural management as is likely to be more environmental friendly and cost effective than chemical fertilization (Souza et al., 2015; Alves et al., 2004; Adesemoye et al., 2009; Hungria et al., 2010, 2013).

Literature analysis and chemical considerations of biological phosphate solubilization have shown that the commonly used source for phosphate solubilisation is tricalcium phosphate (TCP). This is relatively a weak and unreliable as universal selection factor for isolating and testing phosphatesolubilizing bacteria (PSB) (Bashan et al., 2012). This study reports the isolation of potential phosphate solubilising endophytic bacteria from Oryza sativa along with their solubilisation efficiency of three metals of phosphate compounds viz. $\mathrm{Ca}_{3}\left(\mathrm{PO}_{4}\right)_{2}$ (TCP), $\mathrm{FePO}_{4}$ and $\mathrm{AlPO}_{4}$.

\section{Materials and Methods}

\section{Isolation of phosphate solubilising endophytes}

To isolate phosphate-solubilising endophytes, different paddy cultivars were collected from
Lakhimpur district of Assam. Leaves, stems, and roots of healthy and disease free plants were selected for the study. The whole plant was washed with tap water to remove attached debris. Subsequently, leaves, stem and roots were separated and cut into sections 2-3 cm long and washed thoroughly with double distilled water followed by rinsing with $70 \%$ ethanol. The sample was sterilized with $0.1 \% \mathrm{HgCl}_{2}$ and then washed with sterile distilled water for 10 times to remove any traces of the surface sterilizing agents (Gagne et al., 1987). One gram of the sample was homogenized in $10 \mathrm{ml}$ of distilled water to prepare stock solution of tissue homogenate. After appropriate serial dilution the sample was inoculated in Tryptic soya agar (TSA) plates and incubated at $30^{\circ} \mathrm{C}$ for $48-72$ hours. The bacterial colonies that appeared were transferred to $\mathrm{PVK}$ agar, $\mathrm{AlPO}_{4}$ agar, $\mathrm{FePO}_{4}$ in which $\mathrm{FePO}_{4}$ and $\mathrm{AlPO}_{4}$ were replaced as the phosphorous resource in the medium, respectively. The cells were cultured at $30^{\circ} \mathrm{C}$ for 48-72 hours. Strains that could grow in all insoluble phosphate media were selected for further research.

\section{S rRNA gene amplification and sequencing}

Genomic DNA was extracted from five selected isolates as per standard phenolchloroform method (Sambrook and Russel, 2001). The 16S rRNA gene was amplified from the extracted genomic DNA using the universal forward primer $27 \mathrm{~F}$ and the reverse primer 1492R (Lane, 1991). The amplification was carried out in a reaction with a final volume of $25 \mu \mathrm{l}$ containing $1 \mu \mathrm{l}$ (0.5-10 ng) of total DNA, $1 \mu 1$ (20 pico M) of the forward primer, $1 \mu \mathrm{l}(20$ pico $\mathrm{M})$ of the reverse primer, $2.5 \mu 1$ ( $2.5 \mathrm{mM}$ of each) dNTP mix, $2.5 \mu \mathrm{l}$ of 10x PCR buffer, $1 \mu \mathrm{l}(1 \mathrm{U})$ of Taq DNA polymerase. A negative control (PCR mix without DNA) was included in all PCR experiments. The PCR reaction conditions were set for $94^{\circ} \mathrm{C}$ for $4 \mathrm{~min}$, 
followed by 30 cycles of denaturation at $94^{\circ} \mathrm{C}$ for $30 \mathrm{~s}$, annealing at $55^{\circ} \mathrm{C}$ for $1 \mathrm{~min}$ and extension at $72^{\circ} \mathrm{C}$ for $2 \mathrm{~min}$, before a final extension at $72^{\circ} \mathrm{C}$ for $7 \mathrm{~min}$. The PCR products thus obtained were sequenced. The forward and reverse sequences obtained were assembled using the Codon Code Aligner software. Nucleotide sequence identities were determined using the BLAST tool from the National Center for Biotechnology Information (NCBI). Partial sequence data for the 16S rRNA genes have been deposited in the Gen Bank and Gene bank accession numbers have been provided to these sequences.

\section{Quantification of phosphate solubilisation in liquid culture}

Quantitative analysis of solubilization of tricalcium phosphate, aluminium phosphate and iron phosphate in liquid medium was carried out following the protocol described by Nautiyal (1999). The test isolates were inoculated in $50 \mathrm{ml}$ of $\mathrm{Ca}-\mathrm{P}, \mathrm{Al}-\mathrm{P}$, and $\mathrm{Fe}-\mathrm{P}$ broth respectively and incubated for 10 days at $30^{\circ} \mathrm{C}$. After every two days $10 \mathrm{ml}$ of the cultures were centrifuged at $10,000 \mathrm{rpm}$ for $10 \mathrm{~min}$. One $\mathrm{ml}$ of supernatant was mixed with $10 \mathrm{ml}$ of chloromolibidic acid and the volume was made up to $40 \mathrm{ml}$ with distilled water. $1 \mathrm{ml}$ cholorostannous acid was added and the volume was made up to $50 \mathrm{ml}$ with distilled water. Absorbance of the developing blue colour was measured at $600 \mathrm{~nm}$ wave length with UV- VIS spectrophotometer (Spectroquent Pharo 300). The amount of soluble phosphorus was detected from the standard curve of $\mathrm{KH}_{2} \mathrm{PO}_{4}$. Periodic estimation of culture $\mathrm{pH}$ of the medium was performed.

\section{Statistical analysis}

Experimental data were analyzed statistically using MS Excel and SPSS 22.0 software. Significance of variance among the data was calculated by ANOVA analysis and difference between means was compared by LSD tests. The level of significance was set at $\leq 0.05$.

\section{Results and Discussion}

\section{Characterization of phosphate solubilizing bacterial isolates}

Five endophytic bacterial strains isolated from different parts of the rice plant were screened for phosphate solubilizing activity. The 1500 bp region of the 16s rRNA gene showed sequence similarity to Pantoea ananatis, Pseudomonas putida, Brevibacillus agri, Bacillus subtilis and Bacillus megaterium (Table 1).

\section{Bacterial dissolution of phosphate and change in $\mathrm{pH}$ of the medium}

Bacillus subtilis LP31 L03 showed maximum phosphate solubilising activity when TCP was used as the source. Although the isolates, Bacillus subtilis LP31 L03 and Pantoea ananatis RNS 02 solubilized almost equal amount of phosphate $(26.08 \pm 0.51 \mu \mathrm{g} / \mathrm{ml})$ on the second days of incubation, Bacillus subtilis LP31 L03 displayed the highest solubilizing activity by the sixth day of incubation $(56.80 \pm 0.98 \mu \mathrm{g} / \mathrm{ml}$ of phosphate) which was significantly higher than all other isolates under study. The efficiency of all the isolates to solubilise phosphate decreased gradually reaching its zenith on the $10^{\text {th }}$ day (Fig. 1).

Phosphate solubilisation of $\mathrm{FePO}_{4}$ was less as compared to TCP. Most of the isolates solubilised similar amount of phosphate when $\mathrm{FePO}_{4}$ was used as a source until second day of incubation. Solubilization efficiency of the Bacillus subtilis LP31 L03 isolate reached its peak $(7.06 \pm 0.72 \mu \mathrm{g} / \mathrm{ml})$ on 6 DAI, which was quite similar the solubilizing efficiency by Pantoea ananatis RNS $02 \quad(6.25 \pm 0.08$ 
$\mu \mathrm{g} / \mathrm{ml})$ and Pseudomonas putida RNS 04 $(6.68 \pm 0.50 \mu \mathrm{g} / \mathrm{ml})$ (Fig. 2).

The isolates showed similar solubilisation pattern when aluminium phosphate was used as a source of phosphate. Brevibacillus agri RNS 05 showed significantly high solubilisation efficiency $(2.46 \pm 0.18 \mu \mathrm{g} / \mathrm{ml})$ on 2 DAI. However, Bacillus subtilis LP31 L03 displayed higher solubilizing capacity from 4 DAI onwards and continued to reach the maximum $(6.24 \pm .0 .08 \mu \mathrm{g} / \mathrm{ml}$ phosphate) on 6 DAI (Fig. 3).

As the phosphate solubilisation efficiency of the isolates increased, there was a decrease in the $\mathrm{pH}$ of the medium. This was found to decrease to its minimum level on the sixth day, beyond which it increased with concomitant lowering in phosphate solubilisation of the isolates. In the medium inoculated with Bacillus subtilis LP31 L03, $\mathrm{pH}$ significantly reduced to $4.02 \pm 0.12$, $3.33 \pm 0.19$ and $3.8 \pm 0.14$ with TCP, $\mathrm{AlPO}_{4}$ and $\mathrm{FePO}_{4}$ respectively. The $\mathrm{pH}$ was most reduced in the medium containing Aluminium phosphate. On the 8DAI, the $\mathrm{pH}$ of the medium slightly increased with a decrease in solublization of available phosphate. At the end of ten days the $\mathrm{pH}$ of the media were recorded to be $5.0 \pm 0.16,4.0 \pm 0.17,4.5 \pm 0.10$ in TCP, $\mathrm{AlPO}_{4}$ and $\mathrm{FePO}_{4}$ respectively (Fig. 4).

Plant growth and yield are essentially dependent on the availability of minerals which they directly or indirectly acquire from soil in the soluble ionic forms. Soil contains $0.5 \%$ phosphorus, mostly in the form of insoluble mineral complexes which plants cannot absorb (Rengel and Marschner, 2005), only $0.1 \%$ of the total phosphorous exists in a soluble form available for plant uptake (Zou et al., 1992). Phosphate solubilization is a common trait among plant-endophytic bacteria. Phosphate-solubilising bacteria are able to solubilize bound phosphorous from organic or inorganic molecules, by secretion of organic acids and phosphatases thereby making it readily available for the plant (Kim et al., 1998).These organic acids thus produced can chelate the cation bound to phosphate with their hydroxyl and carboxyl groups (Kpomblekou and Tabatabai, 1994).

Fig.1 Phosphate solubilization in TCP

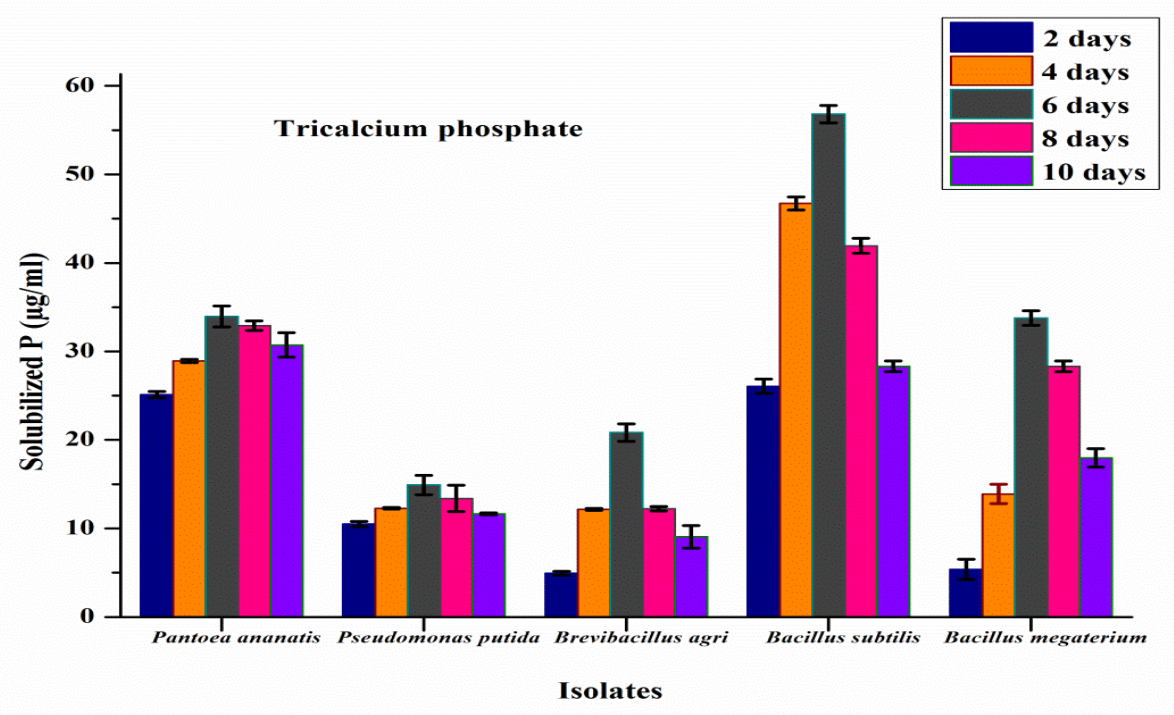


Fig.2 Phosphate solubilization in $\mathrm{FePO}_{4}$

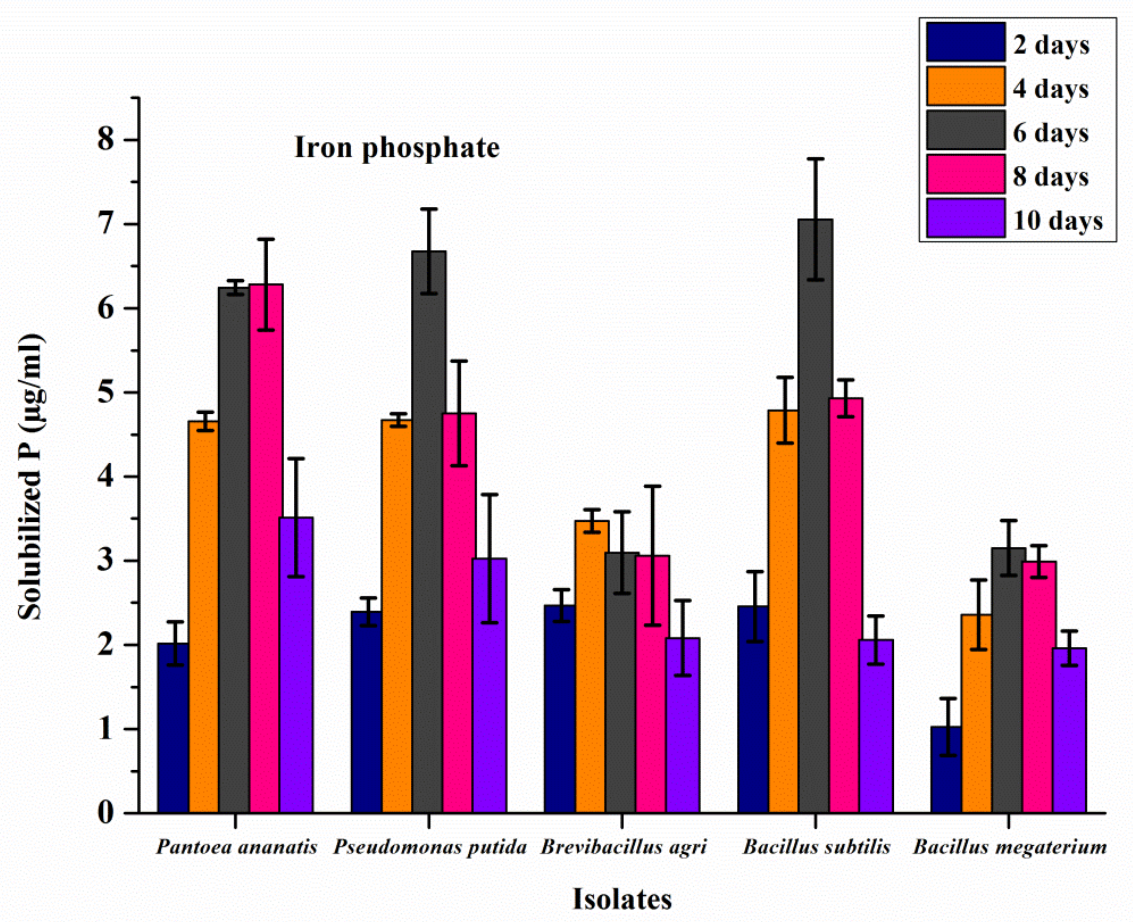

Fig.3 Phosphate solubilization in AlPO4

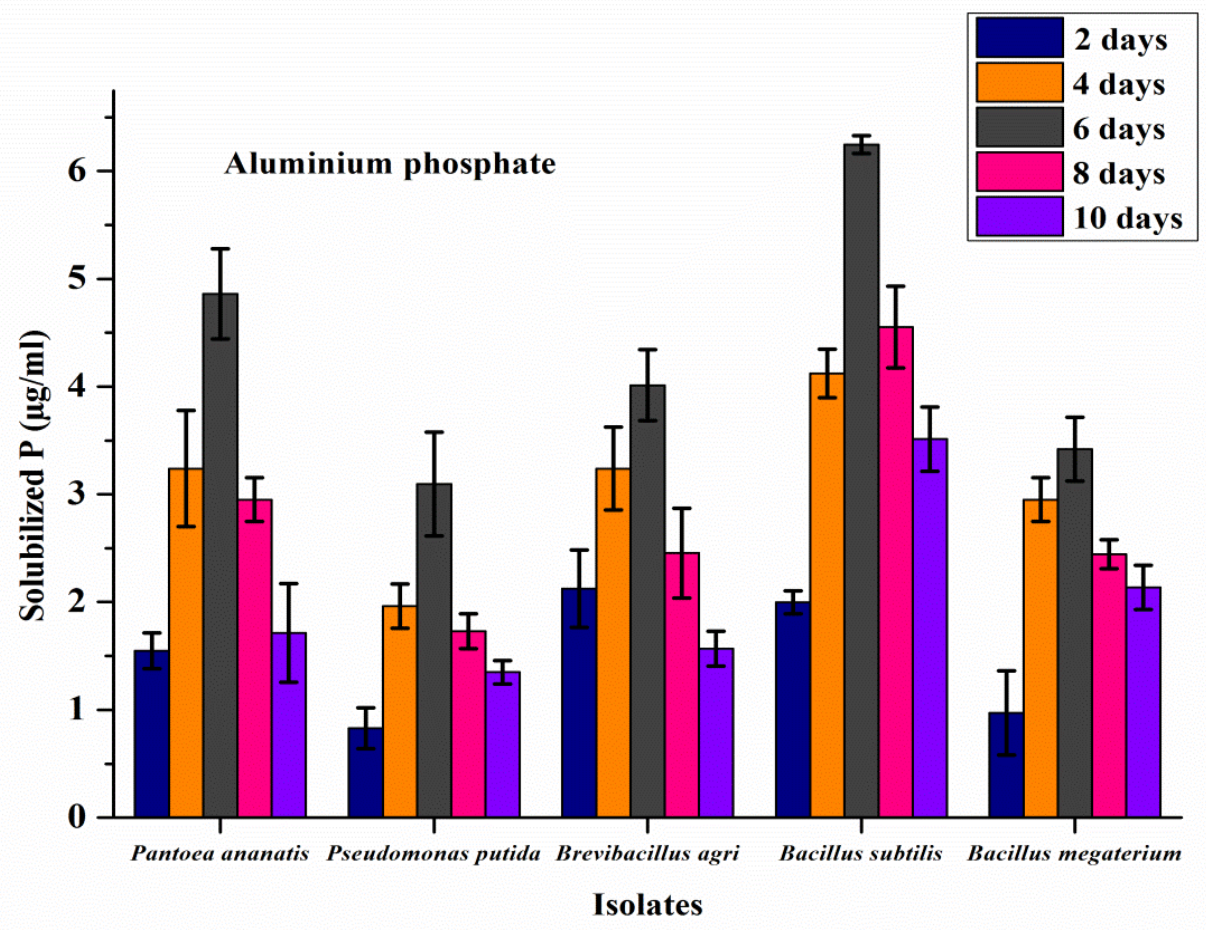


Fig.4 Dynamics of $\mathrm{pH}$ value in different media by Bacillus subtilis

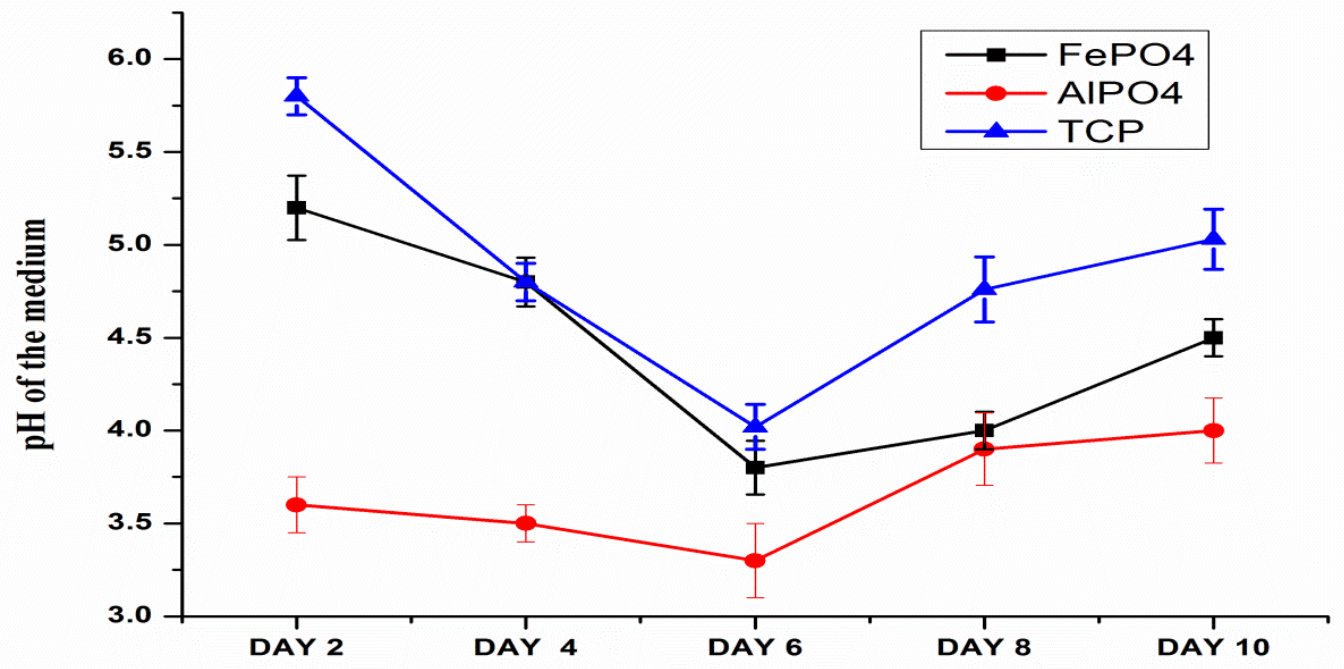

Table.1 Phosphate solubilizing bacteria with their NCBI accession numbers

\begin{tabular}{llllcl}
\hline S No. & Isolate Code & Isolation source & Sequence similarity & Similarity (\%) & Acession No. \\
\hline 1 & RNS 02 & Stem & Pantoea ananatis & 99 & KT380684 \\
\hline 2 & RNS 04 & Stem & Pseudomonas putida & 98 & KX375413 \\
3 & RNS 05 & Stem & Brevibacillus agri & 99 & KX375412 \\
4 & LP31 L03 & Leaf & Bacillus subtilis & 97 & KX375411 \\
\hline 5 & LP31 L04 & Leaf & Bacillus megaterium & 98 & KM350267 \\
\hline
\end{tabular}

Supplementary Data. LSD (least square difference) Analysis

\begin{tabular}{|l|l|l|l|l|l|}
\hline TCP & DAY2 & DAY4 & DAY6 & DAY8 & DAY10 \\
\hline RNS 02 & $25.12 \pm 0.36 \mathrm{a}$ & $28.94 \pm 0.18 \mathrm{a}$ & $33.94 \pm 1.18 \mathrm{a}$ & $33.76 \pm 0.83 \mathrm{a}$ & $30.74 \pm 1.37 \mathrm{a}$ \\
\hline RNS 04 & $10.51 \pm 0.27 \mathrm{~b}$ & $12.27 \pm 0.08 \mathrm{~b}$ & $14.90 \pm 1.10 \mathrm{~b}$ & $13.39 \pm 1.48 \mathrm{~b}$ & $11.66 \pm 0.10 \mathrm{~b}$ \\
\hline RNS 05 & $4.93 \pm 0.21 \mathrm{c}$ & $12.14 \pm 0.10 \mathrm{~b}$ & $20.10 \pm 2.21 \mathrm{c}$ & $12.22 \pm 0.24 \mathrm{~b}$ & $9.05 \pm 1.27 \mathrm{c}$ \\
\hline LP31 L03 & $26.08 \pm 0.51 \mathrm{a}$ & $46.72 \pm 0.73 \mathrm{c}$ & $56.80 \pm 0.98 \mathrm{~d}$ & $41.94 \pm 0.83 \mathrm{c}$ & $28.32 \pm 0.60 \mathrm{~d}$ \\
\hline LP31 L04 & $5.37 \pm 1.15 \mathrm{c}$ & $13.89 \pm 1.08 \mathrm{~d}$ & $33.76 \pm 0.83 \mathrm{a}$ & $28.3 \pm 0.60 \mathrm{~d}$ & $17.96 \pm 1.04 \mathrm{e}$ \\
\hline
\end{tabular}

\begin{tabular}{|l|l|l|l|l|l|}
\hline FePO $_{4}$ & DAY2 & DAY4 & DAY6 & DAY8 & DAY10 \\
\hline RNS 02 & $2.01 \pm 0.25 \mathrm{a}$ & $4.66 \pm 0.11 \mathrm{a}$ & $6.25 \pm 0.08 \mathrm{a}$ & $6.28 \pm 0.54 \mathrm{a}$ & $3.51 \pm 0.70 \mathrm{a}$ \\
\hline RNS 04 & $2.39 \pm 0.16 \mathrm{a}$ & $4.67 \pm 0.07 \mathrm{a}$ & $6.68 \pm 0.50 \mathrm{a}$ & $4.75 \pm 0.62 \mathrm{~b}$ & $3.02 \pm 0.76 \mathrm{ab}$ \\
\hline RNS 05 & $2.46 \pm 0.18 \mathrm{a}$ & $3.47 \pm 0.13 \mathrm{~b}$ & $3.10 \pm 0.48 \mathrm{~b}$ & $3.06 \pm 0.82 \mathrm{c}$ & $2.08 \pm 0.45 \mathrm{~b}$ \\
\hline LP31 L03 & $2.46 \pm 0.42 \mathrm{a}$ & $4.79 \pm 0.39 \mathrm{a}$ & $7.06 \pm 0.72 \mathrm{a}$ & $4.93 \pm 0.22 \mathrm{~b}$ & $2.06 \pm 0.28 \mathrm{~b}$ \\
\hline LP31 L04 & $1.02 \pm 0.33 \mathrm{~b}$ & $2.35 \pm 0.41 \mathrm{c}$ & $3.15 \pm 0.32 \mathrm{~b}$ & $2.98 \pm 0.18 \mathrm{c}$ & $1.96 \pm 0.20 \mathrm{~b}$ \\
\hline
\end{tabular}




\begin{tabular}{|l|l|l|l|l|l|}
\hline AIPO $_{4}$ & DAY2 & DAY4 & DAY6 & DAY8 & DAY10 \\
\hline RNS 02 & $1.54 \pm 0.16 \mathrm{a}$ & $3.24 \pm 0.54 \mathrm{a}$ & $4.86 \pm 0.41 \mathrm{a}$ & $2.95 \pm 0.20 \mathrm{a}$ & $1.71 \pm 0.45 \mathrm{a}$ \\
\hline RNS 04 & $0.82 \pm 0.18 \mathrm{~b}$ & $1.96 \pm 0.20 \mathrm{~b}$ & $3.09 \pm 0.48 \mathrm{~b}$ & $1.72 \pm 0.16 \mathrm{~b}$ & $1.35 \pm 0.10 \mathrm{a}$ \\
\hline RNS 05 & $2.12 \pm 0.35 \mathrm{c}$ & $3.24 \pm 0.38 \mathrm{a}$ & $4.01 \pm 0.32 \mathrm{c}$ & $2.45 \pm 0.37 \mathrm{a}$ & $1.56 \pm 0.16 \mathrm{a}$ \\
\hline LP31 L03 & $1.99 \pm 0.11 \mathrm{ac}$ & $4.12 \pm 0.22 \mathrm{c}$ & $6.24 \pm 0.08 \mathrm{~d}$ & $4.55 \pm 0.37 \mathrm{c}$ & $3.51 \pm 0.29 \mathrm{~b}$ \\
\hline LP31 L04 & $0.97 \pm 0.39 \mathrm{~b}$ & $2.95 \pm 0.20 \mathrm{a}$ & $3.42 \pm 0.29 \mathrm{bc}$ & $2.44 \pm 0.13 \mathrm{a}$ & $2.13 \pm 0.20 \mathrm{a}$ \\
\hline
\end{tabular}

Mean with same letters in each column are not significantly different at $\mathrm{P}<0.05$ according to LSD test

Among all the five isolates, Pantoea ananatis, Pseudomonas putida, Brevibacillus agri, Bacillus subtilis and Bacillus megaterium that could solubilise phosphate existing in the selective sources of phosphate (TCP, $\mathrm{AlPO}_{4}$, $\mathrm{FePO}_{4}$ ), it was Bacillus subtilis isolate that was most efficient in solubilizing maximum amount of all the sources of phosphate tested in this study. The bacterial isolates considered under the study were better able to solubilise TCP when compared to the $\mathrm{FePO}_{4}$ and $\mathrm{AlPO}_{4}$. Sources of phosphorous such a $\mathrm{FePO}_{4}$ and $\mathrm{AlPO}_{4}$ are less soluble than tricalcium phosphate in water (Bashan et al., 2012). Earlier, Fifty-five endophytic PSB that were isolated from sap, leaves, and roots of maize were tested for their ability to solubilize tricalcium phosphate and produce organic acid. Partial sequencing of the 16S rRNAencoding gene showed that the isolates were from the genus Bacillus and different species of Enterobacteriaceae. The phosphate solubilisation, out of the 336 bacteria isolated from rice plants, nearly 101 isolates belonging to the genera Burkholderia, Cedecea, Cronobacter, Enterobacter, Pantoea and Pseudomonas were able to solubilize tricalcium phosphate $\left[\mathrm{Ca}_{3}\left(\mathrm{PO}_{4}\right)_{2}\right]($ Souza et al., 2013). Phosphate solubilisation reached maximum on the 6 DAI with concomitant decrease in $\mathrm{pH}$ of the medium after which the $\mathrm{pH}$ gradually decreased. The decrease in the $\mathrm{pH}$ of the medium may be due to the secretion of organic acids and acid phosphatases by the isolates that helps in phosphate solubilisation (Illmer et al., 1995). In organic acid production mechanisms, gluconic acid is regarded as the most frequent agent of mineral phosphate solubilization. It is reported as the principal organic acid produced by Pseudomonas sp. (Illmer et al., 1992) and Erwinia sp. (Liu et al., 1992). Ketogluteric acid is also reported as one of the major organic acids present in different phosphate solubilizing microbes (Puente et al., 2004; Rodriguez et al., 2006). Besides these two organic acids, glycolic, malonic, oxalic and succinic acids were also identified among phosphate solubilizers gluconic acid (GA) seems to be the most frequent agent. The production of 2-ketogluconic, oxalic, malic, lactic, succinic, formic and citric acid has also been reported in phosphate solubilization by Bacillus sp. (Chen et al., 2006). Gaind and Gaur (1989) reported that the decrease in available phosphate after a period might be due to the deficiency in nutrients in the culture medium or refixation of solubilized phosphate with metal ions present in the broth. However, increase in the acidity of the medium also inhibits the growth of bacteria and decrease their phosphate solubilizing activity. Dhanya et al., 2013 found Bacillus subtilis to show greater reduction in $\mathrm{pH}$ when inoculated in phosphate solubilising liquid media.

Prospecting for beneficial bacteria is an important criterion for the development of new and efficient inoculants for biofertilizer. The present study isolated rice endophytes viz., Pantoea ananatis, Pseudomonas putida, Brevibacillus agri, Bacillus subtilis and Bacillus megaterium that were able to efficiently solubilize different sources of phosphate viz. TCP, $\mathrm{AlPO}_{4}$, and $\mathrm{FePO}_{4}$. This 
suggests that they could play a role in resource mobilization in nutrient-poor habitat. Among the isolates tested, Bacillus subtilis was found to be the most efficient phosphate solubilizer indicating their use in developing commercial phosphate solubilising biofertilizer.

\section{Acknowledgement}

Authors are grateful to the funding organization Department of Biotechnology (DBT), Ministry of Science and Technology, Govt. of India and Department of Agricultural Biotechnology, Assam Agricultural University, Jorhat, Assam for carrying out the research.

\section{References}

Adesemoye, A.O., HA. Torbert and Kloepper, JW. 2009. Plantgrowth-promoting rhizobacteria allow reduced application rates of chemical fertilizers. MicrobEcol. 58: 921-929.

Afzal, A., and Ashgari, B. 2008. Rhizobium and Phosphate Solubilizing bacteria improve the Yield and Phosphorus Uptake in Wheat. Int. J. Agri. Biol. 10(1): 85-88.

Alves, B.J.R., RM. Boddey and Urquiaga, S. 2004. The success of BNF in soybean in Brazil. Plant Soil. 252:1-9.

Bashan, Y., G. Holguin and De-Bashan, LE. 2004. Azospirillum-plant relations physiological, molecular, agricultural, and environmental advances. Can J Microbiol. 50:521-577.

Chen, Y.P., P.D. Rekha, A.B. Arun, F.T Shen, W.A Lai and Young, C. 2006. Phosphate solubilizing bacteria from subtropical soil and their tricalcium phosphate solubilizing abilities. Appl Soil Ecol. 34:33-41.

Gagne, S., C. Richard, H. Roussean and Antoun, H. 1987. Xylem-residing bacteria in alfalfa roots. Can J Microbiol. 33: 996 - 1000.

Gaind, S., and Gaur A.C. Curr. Sci. 1989, 58, 1208-1211.

Hungria, M., R.J. Campo, E.M. Souza and Pedrosa, F. 2010. Inoculation with selected strains of Azospirillum brasilense and A.lipoferum improves yields of maize and wheat in Brazil. Plant Soil. 331:413-425.

Illmer, P., A. Barbato and Schinner, F. 1995. Solubilization of hardly soluble AlPO4 with P-solubilizing microorganisms. Soil Biol. Biochem. 27: 260-270.

Illmer, P.A., and Schinner, F. 1992. Solubilization of inorganic phosphates by microorganisms isolated from forest soil. Soil Biol. Biochem 24: 389-395.

Khan, A.A., G. Jilani, M.S. Akhtar, S. Naqvi and Rasheed, M. 2009. Phosphorus solubilizing bacteria: occurrence, mechanisms and their role in crop production. J AgricBiolSci. 1(1):48-58.

Khan, M.S., A. Zaidi, M. Ahemad, M. Oves and Wani, P.A. (2010). Plant growth promotion by phosphate solubilising fungi-current perspective. Arch.Agric. SoilSci. 56:73-98.

Kim, K.Y., D. Jordan and McDonald, GA.1998. Enterobacter agglomerans, phosphate solubilizing bacteria, and microbial activity in soil: effect of carbon sources. Soil BiolBiochem. 30: 995-1003.

Kpomblekou, A., and Tabatabai, M.A. 1994. Effect of organic acids on release of phosphorus from phosphate rock. Soil Science 158: 442-453.

Liu, T.S., L.Y. Lee, C.Y. Tai, C.H Hung, Y.S. Chang, J. H. Wolfram, R. Rogers and Goldstain, A.H. J.bacterial.1992 174, 5814- 9.

Puente, M.E., Y. Bashan, C.Y Li, and Lebsky,V.K. 2004. Microbial populations and activities in the rhizosphere of rock-weathering desert 
plants. Root colonisation and weathering of igneous rocks. PlantBiol. 6: 629-642.

Rengel, Z., and Marschner, P. 2005. Nutrient availability and management in the rhizosphere: exploiting genotypic differences. New Phytol 168:305-312.

Richardson, A., 2001. Prospect for using soil microorganisms to improve the acquisition of phosphorous by plants. Aust J Plant Physiol 28:897-906.

Rocheli, S., A. Adriana and M.P, Luciane 2015. Genetics and Molecular Biology. 38(4): 401-419.

Rodríguez, H., R. Fraga, T. Gonzalez and Bashan, Y. 2006. Genetics of phosphate solubilization and its potential applications for improving plant growth-promoting bacteria. Plant Soil. 287:15-21.

Sambrook, J., and Russel, D W. 2001. Commonly Used Techniques in Molecular Cloning," Appendix 8, in Molecular Cloning, Volume 3, 3rd edition, by Joseph Sambrook and David W. Russell. Cold Spring Harbor Laboratory Press, Cold Spring Harbor, NY, USA.

Sharma, S.B., R.Z. Sayyed, M.H. Trivedi,
Gobi, T.A. 2013. Phosphate solubilizing microbes: sustainable approach for managing phosphorus deficiency in agricultural soils, vol 2. Springer Plus. 587: 2193-1801.

Souza, R., A. Beneduzi, A. Ambrosini, P.B. Costa, J. Meyer, L. K. Vargas, R. Schoenfeld and Passaglia, L.2013. The effect of plant growth-promoting rhizobacteria on the growth of rice cropped in southern Brazilian fields. PlantSoil. 366:585-603.

Vendan, R.T., Y.Yu, S. Lee and Rhee Y. 2010. Diversity of endophytic bacteria in ginseng and their potential for plant growth promotion. J. Microbiol. 48: 559-565.

Yoav, B., A. Alexande and Luz, E. 2012. Tricalcium phosphate is inappropriate as a universal selection factor for isolating and testing phosphatesolubilizing bacteria that enhance plant growth: a proposal for an alternative procedure, BiolFertil Soils. 49:465-479.

Zou, K., D. Binkley and Doxtader, K.G. 1992. A new method for estimating gross phosphorus mineralization and immobilization rates in soils. Plant Soil 147:243-250.

\section{How to cite this article:}

Madhusmita Borah, Pompi Das, Susanta Sarmah Pathak, Robin Chandra Boro and Madhumita Barooah. 2017. Phosphate Solubilization by Endophytic Bacteria isolated from Oryza sativa. Int.J.Curr.Microbiol.App.Sci. 6(10): 2713-2721. doi: https://doi.org/10.20546/ijcmas.2017.610.319 